\title{
Study of Trademark Parallel Import
}

\author{
Zheng Zhang ${ }^{1}$ \\ Xi'an International University, 710077 \\ hunter2011@foxmail.com
}

Keywords: Parallel Importation; Trademark; Exhaustion of Rights; Conflicts of Interest

\begin{abstract}
Since China joined the World Trade Organization, cases involving trademark parallel imports have risen rapidly, import more and more attention has been paid to trademark parallel explore. To research issue of parallel importation trademark of China's foreign trade has a profound impact. Therefore, this paper chooses the trademark parallel import as research subjects, research trademark system concept of parallel imports, features, forms, causes and so on, comparative analysis and draw legislative, judicial practices in other countries and regions, and ultimately concluded that: China should enact legislation on trademarks and take attitude for trademarks of parallel importation as permit on principle, but there are exceptions.
\end{abstract}

\section{Introduction}

Parallel import has appeared in three areas of intellectual property: patents parallel imports, parallel imports of copyright and trademark parallel imports. Based on three different participants, different balance of interests, the purpose of different behaviors and different normative basis, they should be treated differently, their respective regulations should be separate. Currently, the academic research on parallel imports mainly focused on trademark parallel import, it has also become the subject of this article to explore.

Trademark parallel imports but parallel importation and trademark-related, refers to the international sale of goods, the importer in the case of a State of a trademark has protected its domestic law, without their trademark owner or trademark owners permission from the same foreign legitimate trademark merchandise purchased authentic input their behavior. Trademark parallel import is a transnational commercial activity, the use of fluctuations in international exchange rates importer, regional price difference and other favorable factors, with its good operating environment and sensitive market assessment capabilities, for profit.

\section{Expressions of Trademark Parallel Imports}

The case of the original owner of the trademark are in importing and exporting countries authorized local importers or local manufacturer manufacturing, sales trademark goods, importing countries are still without a third-party trademark licenses from the exporting country imports trademark goods for sale or use.

The case of a state authorized by the trademark owner in another country local importers or local manufacturer manufacturing, selling trademark goods, one of the country's trademark without permission of the third party trademark goods imported from another country to their sale or use .

Presence in the importing and exporting countries are fully independent from each other (non-existent relationship or common authorization from an original owner of the trademark authority) trademark owners, importers unauthorized third party trademark goods imported into the country sales or use.

After the trademark goods are sold to a country without trademark laws protect this trademark, the trademark owner or licensee already importing country presence unauthorized third party trademark goods imported from that country to its own sales or use. 


\section{Reason of Trademark Parallel Imports}

The first one is multinational discriminatory pricing strategy. The so-called price discrimination refers to the control of multinational companies use to market forces, according to the elasticity of demand in the country as a unit varies for different segments of commodity prices, the implementation of market segmentation, in order to seek to maximize global revenue. In general, the larger the market, the higher the level of economic development, the greater the elasticity of demand, the price is higher, and vice versa. The price different between the same kinds of goods in different countries will certainly form different demand elasticity.

The second one is tariff differences. Even multinational companies (provided their country is a State) to take unified global pricing strategy are selling to third countries acetate States and countries of the agents, but when a State B State of import tax rate is higher than for a State with State $\mathrm{C}$ when import tariffs kinds of commodities, the acetate, propionate retail price of the same kinds of commodities between the two countries still differ. Also, because between $\mathrm{B}$ and $\mathrm{C}$ signed a preferential trade agreement between the two countries, mutual exemption of import duties, the cost of imports between the two countries will be very low.

Exchange rate fluctuations. If a country's currency relative appreciation, there must be another country's currency has depreciated, if multinational pricing strategy lags behind exchange rate fluctuations, the country and soft currency countries coin will have different prices the same kinds of commodities. As in 1984 and 1985 for two years, the appreciation of the dollar to remain strong momentum, partly sold in Japan, the United States produced Caterpillar (caterpillar) excavators and loaders for the transaction will be in yen currency exports to the United States, the removal of transport and insurance costs, these imports are still lower than the US this property with brand commodity prices of about $15 \%$. In addition to the above three points, because some countries, such as the extent of the different sectors of the pharmaceutical industry's special price regulation, manufacturers to wholesalers and retailers discount product different from other reasons, will produce the international price difference here is not repeat.

\section{Trademark Parallel Imports Conflicts of Interest and Specific Strategies}

Conflicts of Interest in the Trademark Parallel Imports. Acts of trademark parallel import regulation and adjustment process is actually a multi-stakeholder balance: balance and the balance of international interests and domestic interests of the balance of the interests of producers and consumers' interests, public interests and private interests. States, significant differences in attitudes and regulations in the regions held by the behavior of trademark parallel import and specific regulation reflects the different interests of their conflicting interests and principles in the face of disagreements arising from the trademark parallel imports made when selecting priority protection.

Exhaustion of trademark rights principle is also known as the trademark first sale doctrine. It means that once the product put on the market by the trademark owner or authorized to be put on the market by the legal protection of trademark rights will come to end, the original trademark owner can not prevent or discourage subsequent resale within this market of the product or usage behavior. Exhaustion Doctrine precisely in order to balance the negative effects of the intellectual property owner the exclusive right to produce and set up, and its purpose is to be necessary to restrict the rights of intellectual property owners, in order to avoid excessive monopoly hinder the free flow of products. Among these questions is this: In the exhaustion of rights principle, how to define the market?

If the rights of trademark exhaustion doctrine, principles combined with regional, will have the trademark rights of national or regional exhaustion doctrine, in this case, the market is defined as the domestic market or regional markets. And based on the principle of regional exhaustion of trademark rights, in spite of the trademark owner for resale behavior within a country or a particular region of goods protected by intellectual property law has no right to interfere, but the owner of the trademark according to their own regional knowledge property prevent sales in other regions related 
products have been imported into this area, even if these imports are authorized by the trademark owner under the circumstances to sell the real thing.

If the trademark exhaustion of rights principle and the principle of universality combined constitute trademark rights-the principle of international exhaustion. Based on this principle, as long as the trademark right holders of goods protected by intellectual property to its delivery to any areas of a justice, the trademark owner's exclusive rights in all areas of justice are not longer legal protection. The market here is actually defined as the international market.

Specific Strategies for Trademark Parallel Imports Conflicts. Companies should be cautious signing a trademark license contract, especially involving concession contract and the terms of parallel imports. Franchise is a brand agents to obtain a monopoly position within the scope of its business market basis and guarantee. Franchise has also become an important basis in the current legal system to sue for parallel importers. Thus, the domestic enterprises in the signing a trademark license contract, to try to treat carefully the terms and franchise-related contracts should be clear as to clarify the scope of the exercise of the rights and the rights of specification objects. In addition, if the signing of the following clause in the contract, so as the specific interests of trademark licensees who use domestic enterprises can be better protected: If you find any violations of the rights of the contract award, the contracting parties in line with the principles of honesty and good faith, to take legal measures to deal with the infringer or other appropriate measures to prevent or reduce the damage. The terms associated with parallel imports is concerned, the parties should consider the elaboration of corresponding provisions in the agreement to be certain restrictions on parallel imports. For example, in the contract, trademark license contract the licensee may request the licensee for its worldwide agent or franchisee of the trademark usage unified management and regulation. Again, the two sides also agreed, Licensee sources and exporter possible parallel imports to investigate and control.

Parts of mainland China or get a franchise business should vigorously promote the exclusive right enjoyed by its media and merchandise. This can not only increase the visibility and market competitiveness of enterprises trademark, but also provide strong evidence for future litigation and parallel importers. The so-called know ourselves and know yourself, in the understanding of themselves, promote their own at the same time, it should analyze competitor, infringer situation. Business (particularly those belong to pharmaceutical products, clothing, cosmetics and other industrial enterprises) to deal with smuggling-related merchandise, imports (quality, quantity, and sales) for investigation and analysis, to focus on parallel imports of the parties in the past imports of suspect behavior. This helps businesses and judge outside of court in trademark law, whether there are other laws were violated? Such as whether the country violated the Anti-Unfair Competition Law, or consumer protection law, or criminal law? Thus, companies will expand protection barrier their rights, rather than rely solely on trademark law or equity to seek direct confrontation entity parallel imports.

Chinese enterprises should understand the international rules on IPR protection and study of legislation and judicial practice major national intellectual property to accelerate the training and management of intellectual property, take advantage of the form of domestic and international intellectual property protection to safeguard their interests. For example, in those countries restrict or prohibit the trademark parallel imports, enterprises should be the Trademark Office or other relevant trademark registration. Because the trademark registration in these countries, providing a lot of interest in the relevant entity (including the right to restrict or prohibit the trademark parallel imports) is the trademark owners and users, based on the interests of these entities, when the alleged parallel imported goods out of the mark, the inevitable It will be blocked by the authorities.

\section{Conclusion}

Nowadays, the legislation of trademark parallel import in our country is necessary. Our attitude to trademark parallel importation legislation should be adopted are: to allow parallel importation trademark on principle, but there are exceptions. The reason to set exceptions to better protect the legitimate rights and interests of consumers and safeguard market order of fair competition and 
promote economic growth. However, the proposed regulation herein trademark parallel imports and attitudes are not eternal. They should meet the national needs and comply with the international trend of continuous development and improvement.

\section{References}

[1] Inge Govaere, The Use and Abuse of Intellectual Property Rights in E.C Law, Sweet\& Maxwell Ltd.1996.

[2] Mccarthy. Desk Encyclopedia of Intellectual Property. Mccarthy, Thomas, P118.

[3] L.Ray Patterson, Stanley W. Lindberg: The Nature Of Copyright: A Law of Users’ Right, P49-55.

[4] Ma Wei. Speculative Absence Disease Foreign Language Teaching. 1998(7): 16-19. 